Document downloaded from:

http://hdl.handle.net/10251/156522

This paper must be cited as:

Mehdid, MEA.; Marti-De Olives, A.; Fernández Martínez, N.; Rodríguez Garcia, M.; Peris Ribera, CJ. (2019). Effect of stress on somatic cell count and milk yield and composition in goats. Research in Veterinary Science. 125:61-70.

https://doi.org/10.1016/j.rvsc.2019.05.015

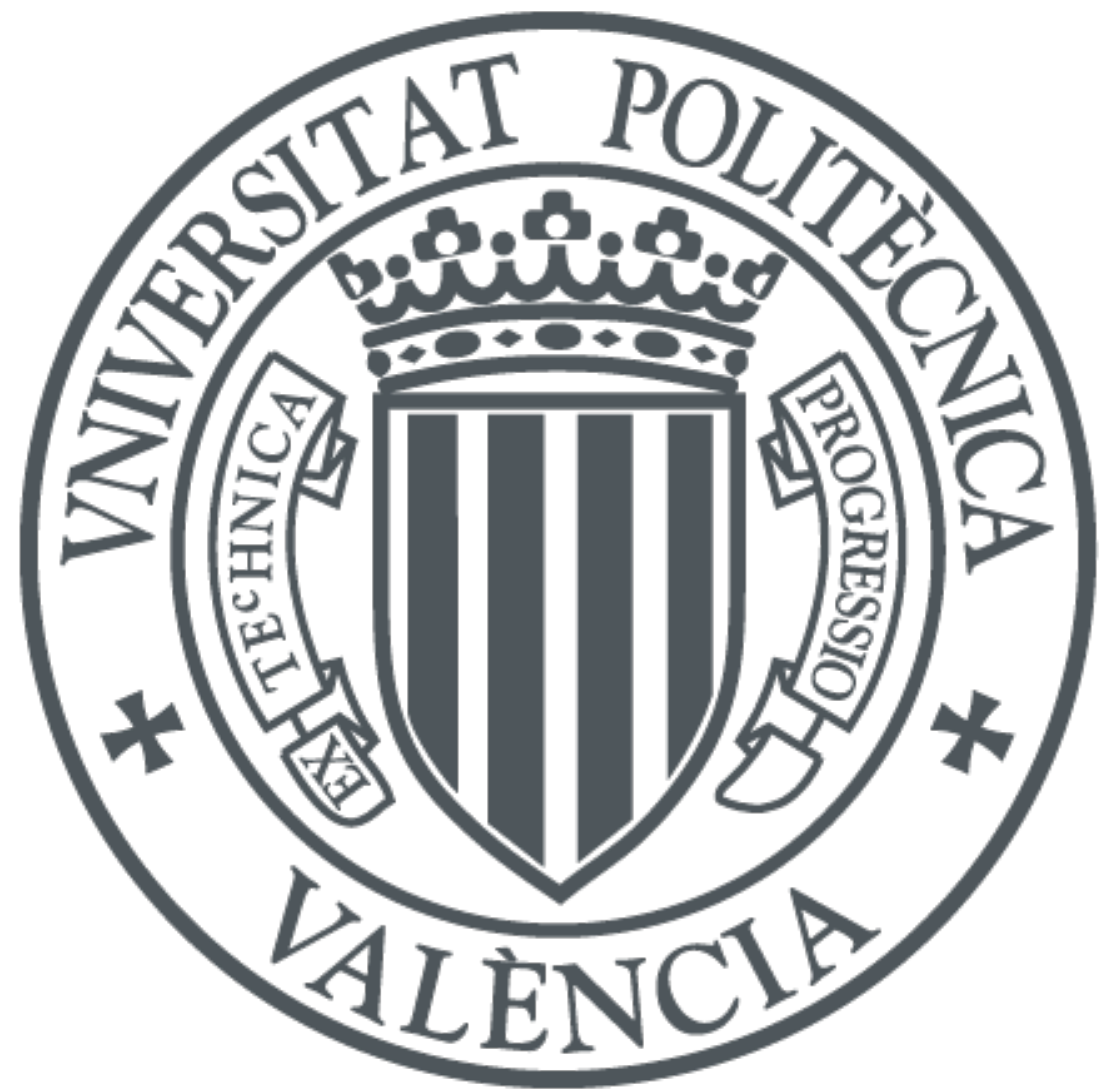

The final publication is available at

https://doi.org/10.1016/j.rvsc.2019.05.015

Copyright Elsevier

Additional Information 


\section{Effect of Stress on Somatic Cell Count and Milk Yield and Composition in Goats}

Amine Mehdid ${ }^{a}$, Ana Martí-De Olives ${ }^{\mathrm{b}}$, Nemesio Fernández ${ }^{\mathrm{a}}$, Martín Rodríguez ${ }^{\mathrm{a}}$, Cristòfol Peris ${ }^{\mathrm{a}, *}$

${ }^{a}$ Institut de Ciència i Tecnologia Animal, Universitat Politècnica de València, Camí de Vera s/n, 46022 València, Spain

${ }^{\mathrm{b}}$ Departamento de Tecnología Agroalimentaria, Escuela Politécnica Superior de Orihuela, Universidad Miguel Hernández, Orihuela, Spain

* Corresponding author at: Institut de Ciència i Tecnologia Animal, Universitat Politècnica de València, Camí de Vera s/n, 46022 València, Spain; cperis@dca.upv.es

E-mail addresses: mma76@yahoo.fr (A. Mehdid), ana.marti@umh.es (A. Martí-De Olives), nfernandez@dca.upv.es (N. Fernández),mrodriguez@dca.upv.es (M. Rodríguez), cperis@dca.upv.es (C. Peris)

\section{ABSTRACT}

There is little information about the effect of the stress on Somatic Cell Count (SCC) and milk yield and composition in goats. A total of 40 goats in their $4^{\text {th }}$ month of lactation were assigned to two groups: stress (STR) and untreated (CON). Goats of STR were exposed to acute stress (visual and auditory stimulus from a barking dog for 20 minutes on day 0). After the stress, average values of plasma cortisol were higher in STR than CON $(\mathrm{P}<0.001)$; likewise, in STR group cortisol was lower in parity $1+2$ goats than parity $\geq 3$ goats $(\mathrm{P}<0.05)$. Stress caused a considerable increase in SCC in parity $\geq 3$ goats $(\mathrm{P}<0.05)$, but not in parity $1+2$ goats. On average, this increase of SCC was 6-fold compared to values prior to the stress, and it was observed in both healthy and infected mammary glands. This increase was transient, as SCC returned to normal values after 1 to 3 days. On day 1, stressed goats of parity $\geq 3$ produced $11 \%$ less milk compared with day 0 and, regarding milk composition, only lactose showed a significant drop. Stressed parity $1+2$ goats showed no changes in SCC and milk yield and composition. We conclude that, in goats, stress is a non-infectious factor 

detection or, in bulk tank milk, as a commercial milk quality parameter.

31 


\section{Introduction}

The somatic cells in milk are leukocytes (neutrophils, eosinophils, macrophages, lymphocytes) derived from blood circulation, as well as cellular debris and mammary epithelial cells, the former being the majority in ruminants (Boutinaud and Jammes, 2002). It is accepted that mammary inflammation, generally of infectious origin, is the main factor in increasing the somatic cell count (SCC)(Harmon, 1994; Raynal-Ljutovac et al., 2007), besides causing negative effects on milk production and quality (Le Maréchal et al., 2011; RaynalLjutovac et al., 2005, 2007; Silanikove et al., 2010;). For this reason, SCC is commonly used in cattle, sheep and goats as a sensitive marker of udder health condition and as a commercial milk quality parameter in bulk tank milk. However, to be able to interpret SCC properly, it is also necessary to take the influence of non-infection factors into account.

One particular feature in goats is that some non-infection factors, such as lactation stage and parity, have a greater influence on SCC than in sheep and cattle (Bergonier et al., 2003; Paape et al., 2007; Raynal-Ljutovac et al., 2007). Thus, in healthy udders the SCC shows a marked increase as the stage of lactation progresses and goats have more parities ( De Crémoux et al., 1996; Dulin et al., 1983; Leitner et al., 2007; Luengo et al., 2004). Moreover, the SCC in goats has demonstrated high daily variability (Randy et al., 1988; Zeng et al., 1997), showing notable transient elevations of SCC lasting 1-3 days, in which the SCC increased 2-20 times within a day. Estrus has been shown to raise the SCC in goats (Christodoulopoulos et al., 2008; McDougall and Voermans, 2002; Moroni et al., 2007) and originate transient elevations of SCC which cannot be explained by variations in milk production (Mehdid et al., 2013). However, whether there are other non-infection factors that can also cause these SCC rises in goats remains unknown. 
There are several factors on farms (management practices, food, type of housing,

environmental conditions) that can end up causing different degrees of stress, affecting the animals' wellbeing. Stress triggers activation of the hypothalamus-pituitary-adrenal axis, an increase in glucocorticoid secretion and a rise in blood leucocytes, together with a reduction of the neutrophils/lymphocytes ratio (Merlot, 2004). In cows, it has been shown that stress caused by transportation increases, in vitro, the migration capacity of neutrophils, which would indicate that they possess a greater capacity to reach the extravascular areas (Yagi et al., 2004). Consequently, we can consider the possibility that a certain degree of stress could increase the SCC in milk. There is very little information available on this aspect in goats. In this specie, some authors suggest that certain apparently stressful situations such as ruminal acidosis, vaccination against enterotoxemia (Lerondelle et al., 1992) and milking (Karzis et al., 2004; Salama et al., 2003) increase the SCC. However, other authors found that the stress induced by 45 minutes of transportation (McDougall et al., 2002) or by application of ACTH (Gaiato et al., 2012) did not affect SCC.

Our hypothesis is that a sufficiently intense stress could give rise to an increase in SCC in the milk obtained at the following milking, although this increase could be different depending on the parity number or mammary gland health status. The aim of the study was to test this hypothesis using goats with different parities (primiparous and multiparous) and mammary health status (with or without intramammary infection- IMI) and to challenge them with a short and acute stress. Milk yield and composition were also determined, and blood cortisol concentration was recorded as a physiological indicator of stress level suffered by the animals (Romero et al., 2015). 


\section{Material and methods}

\subsection{Experimental Design}

The experiment was carried out at the farm of the Universitat Politècnica de València, using Murciano-Granadina dairy goats which were milked once daily (a more frequent practice than twice daily milking in the farms of this goat breed in our geographical area) at 8:30h. Annual health checks performed by official veterinary services showed that the farm was free from brucellosis, tuberculosis, Mycoplasma agalactiae and caprine arthritisencephalitis virus.

A total of 40 goats (14, 6 and 20 of parity 1,2 and $\geq 3$, respectively) in their 4 th month of lactation and housed into three pens (one for primiparous and two for multiparous) were used. Of these animals 23 had healthy udders, 11 unilateral IMI (2, 1 and 8 of parity 1, 2 and $\geq 3$, respectively) and 6 bilateral IMI ( 3 and 3 of parity 2 and $\geq 3$, respectively). All 23 halves udder with IMI showed subclinical infections. One infection was caused by Gram-negative bacilli (coliform) and all the rest by coagulase-negative staphylococci $(S$. simulans, $\mathrm{n}=5 ; S$. epidermidis, $\mathrm{n}=4 ;$ S. xylosus, $\mathrm{n}=3 ;$ S. caprae, $\mathrm{n}=6$; Staphylococcus $\mathrm{spp} ., \mathrm{n}=4)$. The experiment was carried out along 9 consecutive days $(-4,-3,-2,-1,0,1,2,3$ and 4$)$. On day -2 the animals were classified into 2 balanced groups ( $\mathrm{n}=20$ each) according to parity number, udder health status, SCC and milk production. Each group was assigned at random to control (CON) or stress (STR) treatment (Table 1). At 12:30 h of day 0, after milking, goats from group STR were moved to a $70 \mathrm{~m}^{2}$ unfamiliar outdoor pen, situated 50 meters far away from the farm, and exposing them to visual and auditory stimulus from a barking dog for 20 minutes. One worker stayed in the pen, holding the dog's collar by the leash to avoid the dog coming into contact with the goats. Thereafter, goats came back inside the building, to their respective pens for blood sampling, and were kept together with CON goats during the rest of the 
experiment. Variables were recorded in all goats $(n=40)$. Milk production, composition, $\mathrm{SCC}$ by mammary gland and whole udder were monitored daily on each goat during the 9 days of experiment. Blood cortisol was recorded on each goat daily for 7 consecutive days (days -3, 2, -1, 0, 1, 2 and 3). Four bacteriological analyses per mammary gland were performed on each goat on days $-4,-3,1$ and 3 . No presence of abnormal features in mammary secretion (clots, flakes, tints) was recorded during the experiment.

\subsection{Goat management and feeding}

Goats were machine milked once daily $(08: 30 \mathrm{~h})$ in a routine including machine stripping and dipping of the teats in iodine after teatcup removal. The milking parlor $(2 \times 12)$ had 6 clusters (Almatic cluster G50, Delaval Agri, Tumba, Sweden) and a milk pipeline at 1.0 $\mathrm{m}$ above the platform (midlevel). Milking parameters were set at a rate of 90 pulsations per minute, a vacuum level of $40 \mathrm{kPa}$, and a $60 \%$ pulsation ratio. All goats were permanently stabled (available surface $=1.5 \mathrm{~m}^{2} /$ goat; feeder $=0.4 \mathrm{~m} /$ goat) and received the same feed offered per head (as-fed; commercial concentrate for lactating goats $=1.2 \mathrm{~kg} / \mathrm{d}$; alfalfa hay $=$ $1.0 \mathrm{~kg} / \mathrm{d}$; citrus pulp $=2.0 \mathrm{~kg} / \mathrm{d}$; ad libitum barley straw). Water was freely available in the pens.

\subsection{Measured variables}

Total daily milk (machine milk plus machine stripping milk) from each animal was recorded using 3.5-L jars, graduated in 50-mL divisions (Esneder Ref. 90001, Industrias Berango S.L., Urduliz; Spain).

Samples for udder SCC and milk composition analyses were taken from the total milk extracted from each animal in 50-mL polypropylene flasks with a hermetic seal. To determine the SCC per gland, $40 \mathrm{~mL}$ of milk were collected from each teat separately, by manual 
milking before teatcup attachment. All samples, with azidiol as preservative $(0.01 \mathrm{~g}$ of sodium azide $/ 100 \mathrm{ml})$, were kept refrigerated $\left(4^{\circ} \mathrm{C}\right)$ between 24 and $36 \mathrm{~h}$ until analysis in the laboratory. The SCC was analyzed with a Fossomatic 5000 (Foss Electric A/S, Hillerød, Denmark). Milk composition (fat, crude protein, lactose and dry matter) was determined by mid-infrared spectroscopy using a MilkoScan FT120 (Foss Electric A/S).

To obtain half udder samples for bacteriological analysis, teats were carefully cleaned with $70 \%$ ethanol and the first 3 streams of foremilk were discarded. Approximately $5 \mathrm{~mL}$ of milk were collected aseptically from each mammary gland. Samples were kept at $4^{\circ} \mathrm{C}$ for a maximum of $12 \mathrm{~h}$ until bacteriological analysis. Ten microliters of each sample were sowed on blood agar plates (5\% washed sheep erythrocytes; Biomerieux, Lyon, France). Plates were incubated aerobically at $37^{\circ} \mathrm{C}$ and examined at $24 \mathrm{~h}, 48 \mathrm{~h}$, and $7 \mathrm{~d}$. Cultures with 5 or more identical colonies were considered positive for IMI. Bacterial groups were identified according to National Mastitis Council recommendations (NMC, 2017). Identification of staphylococci was performed using commercial micro methods (API ${ }^{\circledR}$ STAPH; BioMèriexu, Lyon, France).

For cortisol analysis, $3.5 \mathrm{~mL}$ of blood samples from the jugular vein of each animal were taken daily, always at 13:00 h, with plastic syringes. Samples were transferred to $5 \mathrm{~mL}$ glass tubes containing $57 \mu \mathrm{l}$ of 15\% EDTA solution (BD Vacutainer K3; Becton, Dickinson and Company, Franklin Lakes, NJ, USA). Samples were centrifuged immediately after collection at $1500 \mathrm{~g}$ for 20 minutes. The blood plasma was distributed into Eppendorf tubes (Eppendorf Iberica SLU, Madrid, Spain) that were frozen and stored at $-40^{\circ} \mathrm{C}$ until analysis. The concentration of cortisol in plasma was analyzed in duplicate at the Animal Physiology Department of the Veterinary Faculty of Complutense University of Madrid (Spain) by the Enzyme Immuno Assay technique (Munro and Lasley, 1988). Cortisol was extracted from 
plasma using $2 \mathrm{ml}$ of diethyl ether. The assay sensitivity was $0.03 \mathrm{ng} / \mathrm{ml}$; the intra- and interassay coefficients of variation were 5.7 and $8.9 \%$, respectively.

\subsection{Definition of a Transient Elevation of SCC}

Only those SCC elevations which fulfilled the following characteristics were considered "Transient Elevation" of SCC (TEsCC) of non-infectious origin: 1) In healthy udders, the SCC of each mammary gland underwent an important rise, of at least 2.5 times compared to the day before; in udders with unilateral IMI, this SCC rise took place in both the healthy half udder and the infected half udder. 2) SCC of udder milk samples also had the same rise described above, reaching values of at least $1,000,000$ cells $/ \mathrm{ml}(700,000$ cells $/ \mathrm{ml}$ in primiparous). 3) After one or several days (normally 1 to 4 days), the SCC of each mammary gland and udder milk sample returned to similar values to those preceding the increase. Goats with bilateral IMI were not considered to identify TEscC of non-infectious origin.

\subsection{Statistical Analysis}

SCC of udder milk samples was analyzed using a repeated measures statistical model with the following effects: Group (CON and STR), Parity (1+2 and $\geq 3$ ), day ( -4 to 4$)$, goat (as random; $\mathrm{n}=1$ to 40) and interactions Group x Day, Group x Parity and Group x Parity x Day. Cortisol, milk yield and composition variables were analyzed with same model but including a covariate (milk yield and composition: for each goat, average for days -4 and -3 ; cortisol: for each goat, result of day -3). SCC and cortisol data were log transformed (Ali and Shook, 1980) to normalize their distribution. The possible interaction between the stress and IMI on SCC was studied with the half udders of parity $\geq 3$ (13 healthy half udders and 7 IMI half udders in both CON and STR groups). So, SCC of these 40 half udders were analyzed, in log, using a repeated measures statistical model with the effects of Group (CON and STR), half 
udder Health Status (IMI or healthy), Day ( -4 to 4 ), half udder (as random; $n=1$ to 40 ) and interactions Group x Day, Group x Health Status and Group x Day x Health Status. All these statistical analyses were performed according to Littell et al. (1998) using the PROC MIXED of the SAS Statistical Package (SAS Institute, 2008).

To study the relationship of SCC increase with the other variables, regression (Proc REG of SAS) and correlation (Proc CORR of SAS) analyses were performed. Proc FREQ was used to compare frequency of ETsCC.

\section{Results}

Plasma cortisol was significantly affected by factors of Group $(\mathrm{P}<0.05)$, Day $(\mathrm{P}<$ 0.001), Group x Day interaction $(\mathrm{P}<0.001)$ and Covariate $(\mathrm{P}<0.01)$; the others factors considered in the statistical model were not significant $(\mathrm{P}>0.05)$. The evolution of plasma cortisol during the experiment, in $\log 10$, is represented in Fig. 1 for Parity $1+2$ goats (Fig. 1a), Parity $\geq 3$ goats (Fig. 1b) and all goats (Fig. 1c). In the three cases, on day 0 log cortisol was significantly $(\mathrm{P}<0.001)$ higher in STR goats compared to CON goats (Fig. $1 \mathrm{c}: 1.3 \pm 0.07$ vs $0.5 \pm 0.07 \mathrm{ng} / \mathrm{ml} ; \mathrm{P}<0.001)$, but differences between both groups were not significant for the remaining days. In addition, we can point out that, in STR goats, the average cortisol values on day 0 was higher in Parity $\geq 3$ goats than in Parity $1+2$ goats $(1.4 \pm 0.09$ vs $1.1 \pm 0.09$ $\mathrm{ng} / \mathrm{ml} ; \mathrm{P}<0.05)$

LogSCC in udder milk was only affected significantly by the factors of Day ( $\mathrm{P}<$ 0.001) and Parity $(\mathrm{P}<0.01)$. as well as the interactions Group $x$ Day $(\mathrm{P}<0.001)$ and Group $\mathrm{x}$ Day $x$ Parity $(\mathrm{P}<0.001)$. This triple interaction is related with the different evolution of $\operatorname{logSCC}$ along days of the experiment according the Group and Parity factors. So, in Parity 
$1+2$ goats the stress did not increase the SCC in STR group compared with CON group (Fig. $2 \mathrm{a}$ and $3 \mathrm{a})$. However, in Parity $\geq 3$ goats, $\operatorname{logSCC}$ of STR group showed an significant increase on day 1 compared to CON group $(\log \mathrm{SCC}=6.50 \pm 0.165$ vs $5.90 \pm 0.165$ cells $/ \mathrm{ml}$, respectively; $\mathrm{P}<0.05$; Fig. $2 \mathrm{~b}$ ). The SCC increase in STR was 6-fold with respect to the values prior to the stress $(3.1$ million cells $/ \mathrm{ml}$ and 0.49 million cells $/ \mathrm{ml}$, for geometric means of SCC on days 1 and 0 , respectively; Fig. 3b). With respect to the Parity factor, $\operatorname{logSCC}$ was lower in Parity $1+2$ goats than in Parity $\geq 3$ goats $(5.34 \pm 0.109$ vs $5.87 \pm 0.109$ cells $/ \mathrm{ml}$, respectively; $\mathrm{P}<0.01)$.

During the experiment, no Parity $1+2$ goats in the CON and STR groups presented a TEsCC, according to the definition specified in Materials and Methods. In Parity $\geq 3$ goats, we identified a significantly $(\mathrm{P}<0.05)$ more frequency of TEsCC in STR group $(7$ of 8 goats with healthy or unilateral IMI udders) than in CON group (2 of 9 goats). In group STR all TEsCC appeared on day 1 and lasted for 1 day ( 2 goats of parity=3), 2 days ( 2 goats of parity=3 and 4) and 3 days ( 3 goats of parity $\geq 4$ ), before returning to the previous values. In the $\mathrm{CON}$ group, the 2 cases of TESCC appeared on day -1 and lasted for 2 days $(2$ goats of parity $=3$ and 4).

At mammary gland level (only Parity $\geq 3$ goats), $\operatorname{logSCC}$ was affected significantly by the factors Day $(\mathrm{P}<0.001)$ and half udder Health Status (healthy: $5.48 \pm 0.050$; infected: 6.18 \pm 0.068 cells $/ \mathrm{ml} ; \mathrm{P}<0.001)$, as well as the interactions Group $\mathrm{x}$ Day $(\mathrm{P}<0.001)$ and Group $\mathrm{x}$ Day $\mathrm{x}$ half udder Health Status $(\mathrm{P}<0.01)$. On day $1, \operatorname{logSCC}$ of parity $\geq 3$ goats was significantly higher in STR group with respect to $\mathrm{CON}$ group $(\log \mathrm{SCC}=6.50 \pm 0.074$ vs 5.84 \pm 0.074 cells $/ \mathrm{ml}$, respectively; $\mathrm{P}<0.001$; Figure $4 \mathrm{c}$ ), and this increase was observed in both healthy mammary glands (Figure 4a) and infected mammary glands (Figure 4b). On day 2, SCC continued to be significantly higher in STR group with respect to the CON group when considering only healthy half udders $(\mathrm{P}<0.05$; Fig. $4 \mathrm{a})$ or all the half udders $(\mathrm{P}<0.01$; 
Figure 4c). Moreover, we can highlight that stress caused the SCC of healthy mammary glands to increase until reaching similar values to the infected mammary glands of nonstressed goats ( $\log$ SCC: $6.23 \pm 0.120$ vs $6.25 \pm 0.088$ cels $/ \mathrm{ml} ; \mathrm{P}>0.05)$. The increase in SCC due to stress depended on the previous values, but the trend was different depending on the definition of this increase. If increase is expressed as difference (SCC day $1-\mathrm{SCC}$ day 0), this was higher in the mammary glands that already set out with a high SCC (Fig. 5a; $\mathrm{r}^{2}=0.70$; $\mathrm{P}<0.001$ ). On the contrary, if the increase in SCC is expressed as a ratio (SCC day 1/SCC day 0 ), this tended to diminish in the mammary glands with higher counts beforehand (Fig. $\left.5 b ; r^{2}=0.23 ; \mathrm{P}<0.05\right)$.

With respect to milk yield and composition, statistical analysis results showed that, in each of these variables, its covariate was significant $(\mathrm{P}<0.001)$ while the Group and Parity factors and Group x Day and Group x Parity interactions were not significant $(\mathrm{P}>0.05)$. The Day factor only affected to milk yield and protein significantly $(\mathrm{P}<0.001$ in both cases). Finally, the triple interaction Group x Parity x Day was significant only for the milk yield $(\mathrm{P}<0.001)$ and lactose $(\mathrm{P}<0.05)$ variables. Table 2 presents the milk yield and composition results on day 1 (first milking after the stress was applied), according to Group and Parity. We can see that stressed parity $\geq 3$ goats presented lower milk production and lower lactose content compared to CON goats of parity $\geq 3$; these differences were small (drop of $11.4 \%$ in milk yield and $2.9 \%$ in lactose $)$ but statistically significant $(\mathrm{P}<0.01$; Table 2$)$. In contrast, in goats of parity $1+2$, these two variables did not present significant differences between CON and STR group goats (Table 2). On day 1, fat, protein and dry matter variables did not differ significantly between STR and CON groups (Table 2). On the other days of the experiment, milk yield and composition variables did not differ significantly between the two groups studied, both in the goats of Parity $1+2$ and in Parity $\geq 3$ and considering all goats. 

day 1 had no significant correlation with plasma cortisol (day 0) or with milk yield decrease (day 1). Moreover, in these goats the correlation between milk yield decrease on day 1 and plasma cortisol (day 0) was not significant either.

\section{Discussion}

This work has experimentally demonstrates, for the first time to our knowledge, that stress can cause a marked elevation of SCC in lactating goats of parity $\geq 3$. This increase is transitory with a duration of 1 to 3 days, which is similar to the effect of estrus in goats (Mehdid et al., 2013). Although the increase of SCC presented a great individual variability (from 2.5-fold to 35-fold higher than the SCC values previous to stress), the average was higher than the increase produced by estrus (6-fold increase in this work and 3.5 and 4-fold for the estrus; Mehdid et al., 2013; Moroni et al., 2007). The fact that all the TEscc in the STR group were concentrated on day 1 suggests that they were caused by the stress suffered by the animals on day 0 . In the CON group, we also identified two cases of TESCC (both on day -1), so it is possible that they were caused by estrus. In any case, both non-infection factors, stress and estrus, raised the SCC sufficiently enough to interfere in its use as an indirect detection method for IMI or, in bulk tank milk, as a commercial milk quality parameter.

Another notable aspect is that the increase in SCC due to stress was only found in Parity $\geq 3$ goats, but not in the younger animals. This is a difference compared to the effect of estrus, as this factor also produces an augmentation of SCC in primiparous goats (Mehdid et al., 2013). Romero et al. (2015) did not find that acute stress for 5 minutes increased the SCC, but these authors only used primiparous IMI-free goats, which would coincide with what we observed in the present work. Other authors did not find that the stress induced by 45 minutes 
of transportation (McDougall et al., 2002) or by application of ACTH (Gaiato et al., 2012) affected SCC, but in both studies the distribution of goats according to parity number was not described and, therefore, we cannot know if it differs with our results. In ewes aged from 4 to 6 years subjected to stress (isolation test for 10 minutes), Caroprese et al. (2010) observed that SCC was higher in high-cortisol ewes than in low-cortisol ewes, but the differences were small (geometric means of 0.426 and 0.223 million cells $/ \mathrm{ml}$, respectively). Regarding the cortisol records in our experiment, we must specify that in order to rule out any possible circadian variation, the blood samples were taken at the same time each day, at 13:00 $\mathrm{h}$, that is, at a time of day when the cortisol levels are low in non-stressed goats (Kokkonen et al., 2001; Romero et al., 2015). Two hypotheses could be formulated to explain the different behavior of the goats with three or more lactations compared to the younger goats. The first hypothesis would be that the younger goats suffered less stress (despite the fact that all received the same treatment), as the average for cortisol was lower in parity $1+2$ than parity $\geq 3$ goats; this low stress would be insufficient to trigger an increase of leukocytes in the blood and/or increased leukocyte transfer to the mammary gland and milk. However, two aspects prompt us to question this initial hypothesis: a) three goats of parity $1+2$ and three goats of parity $\geq 3$ had similar cortisol values $(22-30 \mathrm{ng} / \mathrm{ml})$ but only the latter shown an increase of SCC.; b) in stressed goats of parity $\geq 3$, no significant correlation was observed between cortisol (on day 0) and the increase in SCC (on day 1). The second hypothesis would be that as goats grow older or undergo more lactations, anatomical-physiological changes are generated in the mammary gland that would allow a greater transfer of leukocytes from blood to milk. This hypothesis is coherent with the fact that in healthy udders the SCC is higher in parity $\geq 3$ goats than in primiparous goats (De Cremoux et al., 1996; Leitner et al., 2007; Luengo et al., 2004). 

In $77 \%$ of the healthy glands (10 of 13$)$ SCC values higher than 1 million cells/ml were reached, i.e., counts higher than the single threshold suggested by some authors for the detection of IMI in goats (Contreras et al., 1996; Haenlein, 2002; Bergonier et al., 2003). Moreover, We can also highlight that the increase in SCC due to stress (as difference: SCC day 1 - SCC day 0) tended to increase as the cell counts presented by the mammary glands rose. This suggests that the impact of stress on the SCC of bulk milk will be greater in herds that present a high percentage of goats $\geq 3$ parities, and the higher the prevalence of IMI, as SCC increases with parity and presence of IMI (Raynal-Ljutovac et al., 2007). SCC of bulk milk is used as an indicator of the health status of the herd and, in addition, many industries use it to set the price of goat milk to be paid to farmers (Pirisi et al., 2007). So, given that stress and estrus give rise to transitory elevations of SCC in goats, the interpretation of SCC at goat level (IMI detection) or bulk tank level should never be based on a single milk sample, but rather in several samples taken at intervals of at least one week. production was minor (near to $11 \%$ ) and similar to that found due to estrus effect (decrease of 13\%; Mehdid et al., 2013), and is not enough to explain the increase in SCC. The fact that in these animals the stress also slightly lowered the lactose content in the milk could be related with the drop in the milk production, as lactose is the primary osmotic regulator of milk volume (Baumgard et al., 2017). The effect of stress on lactose is in agreement with Sano et al. (1985), as these authors found that a severe heat stress decreased the mammary glucose uptake and the lactose concentration in goat milk. The fact that stress in the parity $1+2$ goats did not affect the milk yield and composition agree with Romero et al. (2015) who found the same result when IMI-free primiparous goats suffered an acute stress for 5 minutes. Gaiato et al. (2012) found no alteration of quantitative and composition of milk produced in goats 
punctually stressed via application of $\mathrm{ACTH}$, but in this study the distribution of goats according to parity number was not described. In ewes, Caroprese et al. (2010) also found that a short-term acute stress had no effect on the secretion of milk components. In any case, the fact that goats have a great ability to adapt to harsh environments (Silanikove, 2000) could explain the limited impact of the stress on the milk yield and composition.

\section{Conclusions}

In this work we have demonstrated that an acute and punctual stress caused a considerable rise of SCC in goats $\geq 3$ parities. This increase was transitory, as the animals recovered the pre-stress counts in a period of 1 to 3 days, and took place both in healthy and infected mammary glands. In these goats, the milk production was also slightly reduced (drop of $11 \%$ ), along with lactose. In the younger goats, the stress studied did not affect the SCC and milk yield and composition. We conclude that, in goats, stress is a non-infection factor that can interfere with the use of SCC as an indirect method for detection of IMI or, in bulk tank milk, as a commercial milk quality parameter.

\section{References}

Ali, A.K.A., Shook, G.E., 1980. An optimum transformation for somatic cell concentration in milk. J. Dairy Sci. 63, 487-490.

Baumgard, L.H., Collier, R.J., Bauman, D.E., 2017. A 100-year review: regulation of nutrient partitioning to support lactation. J.Dairy Sci. 100, 10353-10366.

Bergonier, D., Decrémoux, R., Rupp, R., Lagriffoul, G., Berthelot, X., 2003. Mastitis of dairy small ruminants. Vet. Res. 34, 689-716.

Boutinaud, M., Jammes, H., 2002. Potential uses of milk epithelial cells: a review. Reprod. 
Nutr. Dev. 42, 133-147.

354

355

Caroprese, M., Albenzio, M., Marzano, A., Schena, L., Annicchiarico, G., Sevi, A., 2010. Relationship between cortisol response to stress and behavior, immune profile, and production performance of dairy ewes. J. Dairy Sci. 93, 2395-2403.

Christodoulopoulos, G., Solomakos, N., Katsoulos, P.D., Minas, A., Kritas, S.K., 2008. Influence of oestrus on the heat stability and other characteristics of milk from dairy goats. J. Dairy Res. 75, 64-68.

Contreras, A., Sierra, D., Corrales, J.C., Sánchez, A., Marco, J., 1996. Physiological threshold of somatic cell count and California Mastitis Test for diagnosis of caprine subclinical mastitis. Small Rumin. Res. 21, 259-264.

De Crémoux, R., Pillet, R., Ducelliez, M., Heuchel, V., Poutrel, B., 1996. Influence du nombre et du stade de lactation sur les numérations cellulaires du lait de chèvre. [Influence of number and stage of lactation on goat milk cell counts], in: Rubino, R. (Ed.), Proceedings of the Somatic Cells and Milk of Small Ruminants. Bella, Italy, September 25-27, 1994. EQQP Publication No 77, Wageningen Pers, pp. 161-165 (in French).

Dulin, A.M., Paape, M.J., Schultze, W.D., Weinland, B.T., 1983. Effect of Parity, Stage of Lactation, and Intramammary Infection on Concentration of Somatic Cells and Cytoplasmic Particles in Goat Milk. J. Dairy. Sci. 66, 2426-2433.

Gaiato, A.P.R., Delgado, T.G.F., Negrão, J.A., 2012. Qualidade e quantidade do leite produzido por cabras da raça Saanen submetidas a estresse por três dias consecutivos. [Quality and quantity of milk produced by Saanen goats submitted to stress during three sequential days]. Arq. Bras. Med. Vet. Zootec. 64, 1373-1380.

Haenlein, G.F.W., 2002. Relationship of somatic cell counts in goat milk to mastitis and productivity. Small Rumin. Res. 45,163-178.

Harmon, R.J., 1994. Physiology of mastitis and factors affecting somatic cell counts. J. Dairy Sci. 77, 2103-2112. 
Karzis, J., Donkin, E.F., Petzer, I.M., 2004. Antibiotic residue whithdrawal periods in milk of saanen dairy goats and udder tissue irritation: preliminary results. South African J. Anim. Sci. 34, 262-265 (supp1).

Kokkonen, U.M., Riskilä, P., Roihankorpi, M.T., Soveri, T., 2001. Circadian variation of plasma atrial natriuretic peptide, cortisol and fluid balance in the goat. Acta Physiol. Scand. 171, 1-8.

Le Maréchal, C., Thiéry, R., Vautor, E., Le Loir, Y., 2011. Mastitis impact on technological properties of milk and quality of milk products-a review. Dairy Sci. \& Technol. 91, 247282.

Leitner, G., Merin, U., Lavi, Y., Egber, A., Silanikove, N., 2007. Aetiology of intramammary infection and its effect on milk composition in goat flocks. J. Dairy Res. 74, 186-193.

Lerondelle, C., Richard, Y., Issartial, J., 1992. Factors affecting somatic cell counts in goat milk. Small Rumin. Res. 8, 129-139.

Littell, R.C., Henry, P.R., Ammerman, C.B., 1988. Statistical analysis of repeated measures data using SAS procedures. J. Anim. Sci. 76, 1216-1231.

Luengo, C., Sánchez, A., Corrales, J.C., Fernández, C., Contreras, A., 2004. Influence of intramammary infection and non-infection factors on somatic cell counts in dairy goats. J. Dairy Res. 71, 169-174.

McDougall, S., Voermans, M., 2002. Influence of estrus on somatic cell count in dairy goats. J. Dairy Sci. 85, 378-383.

McDougall, S., Anniss, F.M., Cullum, A.A., 2002. Effect of transport stress on somatic cell counts in dairy goats. In Proceedings of New Zealand Society of Animal Health. Vol. 62, $16-18$

Mehdid, A., Díaz, J.R., Martí, A., Vidal, G., Peris, C., 2013. Effect of estrus synchronization on daily somatic cell count variation in goats according to lactation number and udder health status. J. Dairy Sci. 96, 4368-4374.

Merlot, E., 2004. Conséquences du stress sur la fonction immunitaire chez les animaux d'elevage.[Consequences of stress on immune function in farm animals] INRA Prod. Anim.17, 255-264.

Moroni, P., Pisoni, G., Van Lier, E., Acuña, S., Damian, J.P., Meiker, A., 2007. Influence of estrus of dairy goat on somatic cell, milk trait, and sex steroid receptors in the mammary gland. J. Animal Sci. 90, 790-797

Munro, C.J., Lasley, B.L., 1988. Non-radiometric methods for immunoassay of steroid hormones. Progress in Clinical and Biological Research 285, 289-329. 
NMC, 2017. Laboratory handbook on bovine mastitis, third ed. National Mastitis Council, Minnesota, USA.

Paape, M. J., Wiggans, G.R., Bannerman, D.D., Thomas, D.L., Sanders, A.H., Contreras, A., Moroni, P., Miller, R.H., 2007. Monitoring goat and sheep milk somatic cell counts. Small Rumin. Res. 68, 114-125.

Pirisi, A., Lauret, A., Dubeuf, J.P., 2007. Basic and incentive payments for goat and sheep milk in relation to quality. Small Rumin. Res. 68, 167-178.

Randy, H.A., Wildman, E.E., Caler, W.A., Tulloch, G.L., 1988. Effect of age and time of milking on day-to-day variation in milk yield, milk constituents and somatic cell counts. Small Rumin. Res. 1, 151-155.

Raynal-Ljutovac, K., Gaborit, P., Lauret, A., 2005. The relationship between quality criterio of goat milk, its technological properties and the quality of the final products. Small Rumin. Res. 60, 167-177.

Raynal-Ljutovac, K., Pirisi, A., De Cremoux, R., Gonzalo, C., 2007. Somatic cells and goat and sheep milk: analytical, sanitary, productive and technological aspects. Small Rumin. Res. 68, 126-144.

Romero, G., Restrepo, I., Muelas, R., Bueso-Ródenas, J., Roca, A., Díaz, J.R., 2015. Withinday variation and effect of acute stress on plasma and milk cortisol in lactating goats. J. Dairy Sci. 98, 832-839.

Salama A.A.K., Such, X., Caja, G., Rovai, M., Casals, R., Albanell, E., Marín, M.P., Martí, A., 2003. Effects of once versus twice milking throughout lactation on milk yield and milk composition in dairy goats. J. Dairy Sci. 86, 1673-1680.

Sano, H., Ambo, K., Tsuda, T., 1984. Blood glucose kinetics in whole body and mammary gland of lactating goats exposed to heat. J. Dairy Sci., 68, 2557-2564.

SAS Institute, 2008. SAS User's Guide: Statistics. Version 9.2 ed. SAS Inst. Inc., Cary, NC.

Silanikove, N., 2000. The physiological basis of adaptation in goats to harsh environments. Small Rumin. Res. 35, 181-193.

Silanikove, N., Leitner, G., Merin, U., Prosser, C.G., 2010. Recent advances in exploiting goat's milk: quality, safety and production aspects. Small Rumin. Res. 89: 110-124.

Yagi, Y., Shiono, H., Chikayama, Y., Ohnuma, A., Nakamura, I., Yayou, K.I., 2004. Transport stress increases somatic cell in milk, and enhances the migration capacity of peripheral blood neutrophils of dairy cows. J. Vet. Med. Sci. 66, 381-387.

Zeng, S.S., Escobar, E.N., Popham, T., 1997. Daily variations in somatic cell count, composition, and production of Alpine goat milk. Small Rumin. Res. 26, 253-260. 
448 